\title{
The Oldest Camel Footprints from Mexico
}

\author{
Eduardo Jiménez-Hidalgo, Rosalía Guerrero-Arenas
}

Eduardo Jiménez-Hidalgo

eduardojh@zicatela.umarmx

Rosalía Guerrero-Arenas

Laboratorio de Paleobiología, Instituto de Recursos, campus Puerto Escondido, Universidad del Mar, Km 2.5, Carretera Puerto Escondido - Oaxaca, C.P. 71985, Oaxaca, Mexico.

BOL. SOC. GEOL. MEX. 2018

VOL. 70 NO. 2

P. $351-359$

http://dx.doi.org/10.18268/BSGM2018v70n2a5

\section{ABSTRACT}

Camel footprints have a well preserved record in Neogene strata from North America, including Mexico, however their Paleogene record is much less known. Here, we describe the oldest camel footprints from Mexico, located in the outskirts of Tezoatlán de Segura y Luna, northwestern Oaxaca, southern Mexico. The camel footprints are preserved as concave epirelief in fine-grained tuffaceous sandstone of the late Eocene-early Oligocene Huajuapan Formation. These footprints display the diagnostic features of Lamaichnum guanicoe, such as bidigital tracks with pointed anterior ends and rounded posterior ends, with digit impressions that do not converge anteriorly and footprints that have digit imprints connected. Potential track makers include Paratylopus, Paralabis and Pseudolabis. The concave axial surface and nail imprints of the Oaxacan footprints, indicate that the track makers shared some anatomical foot features with extant camels, suggesting that some characteristics of the peculiar camel foot had already evolved by the late Eocene-early Oligocene.

\section{Keywords: \\ Camelidae, Lamaichnum guanicoe, Eocene- Oligocene, Tezoatlán, Oaxaca, Mixteca.}

\section{RESUMEN}

En los estratos del Neógeno norteamericano, incluyendo a México, existe un registro de huellas de camélidos bien preservado; sin embargo, el registro del Paleógeno es mucho menos conocido. En este artículo describimos las huellas de camello más antiguas de México, procedentes de los alrededores de Tezoatlán de Segura y Luna, noroeste de Oaxaca, sur de México. Las impresiones de huellas están preservadas como epirelieves cóncavos en areniscas tobáceas del Eoceno tardío-Oligoceno temprano de la Formación Huajuapan. Las huellas se identificaron como Lamaichnum guanicoe, debido a los rasgos que presentan, los cuales incluyen: huellas bidigitígradas con bordes anteriores acuminados y bordes posteriores redondeados, impresiones de dígitos que no convergen anteriormente e impresiones de dígitos conectadas. Los productores potenciales de las huellas incluyen a Paratylopus, Paralabis y Pseudolabis. La superficie axial cóncava y las impresiones de uñas de las huellas oaxaqueñas, indican que los productores compartían algunas características anatómicas podiales con los camellos actuales. Lo anterior, sugiere que algunas características anatómicas del pie de los camellos recientes habian evolucionado ya en el Eoceno tardio-Oligoceno temprano.

Palabras clave: Camelidae, Lamaichnum guanicoe, EocenoOligoceno, Tezoatlán, Oaxaca, Mixteca. 


\section{Introduction}

Camel footprints are relatively well recorded in North American Neogene strata, geographically ranging from western Canada to central Mexico (Lucas and Hunt, 2007). In contrast, the Paleogene record is scarce; published records include those from the Oligocene of South Dakota and probably the Eocene of Texas (Chaffee, 1943; Bjork, 1976; Sarjeant and Langston, 1994).

In Mexico, camel ichnites have been formally reported from the Miocene of Durango (El Salto), associated with a turkey-like tracks (Lockley and Delgado, 2007; Lockley and Bishop, 2014); from the Plio-Pleistocene of Jalisco (San Juan de los Lagos), associated with bird, proboscidean and felid ichnites (Rodríguez-de la Rosa and Guzmán-Gutiérrez, 2012); from the Plio-Pleistocene of southern Puebla (Tepexi de Rodríguez), where the camel footprints are associated with bird footprints, two kinds of felid footprints, proboscidean and small ruminant footprints (Cabral-Perdomo, 2013; Jiménez-Hidalgo et al., 2015a); and from the Plio-Pleistocene of southeastern Puebla (Tehuacán), where camel footprints are associated with canid ichnites (Dávalos-Álvarez et al., 2007; Rodríguez-de la Rosa and Guzmán-Gutiérrez, 2012) (Figure 1).
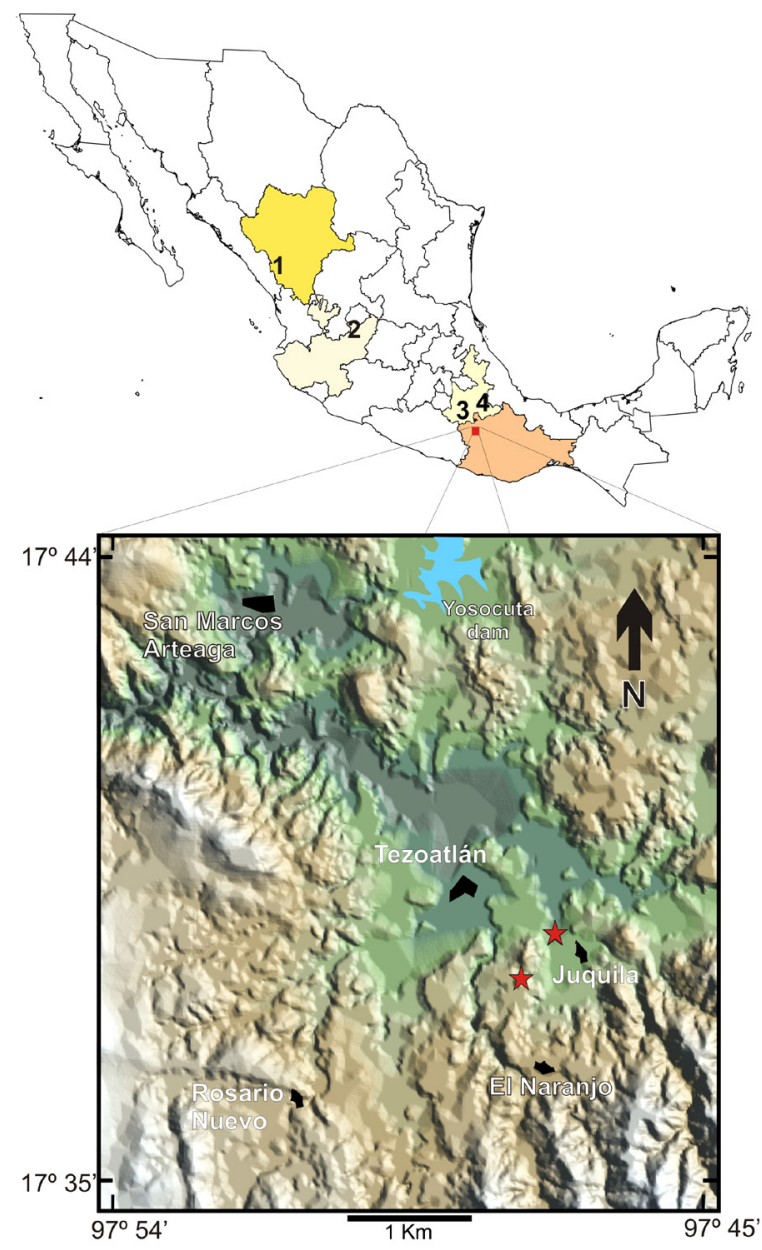

Figure 1 Map of Mexico showing the states with camel footprint records and a hypsometric map of the study area in Tezoatlán de Segura y Luna, Oaxaca, southern Mexico. 1. El Salto, Miocene of Durango; 2. San Juan de los Lagos, Plio-Pleistocene of Jalisco; 3. Tepexi de Rodríguez, Plio-Pleistocene of Puebla; 4. Tehuacán, Plio-Pleistocene of Puebla. The red stars indicate the ichnofossil localities of late Eocene-early Oligocene age in the outskirts of Tezoatlán, Oaxaca. 
2
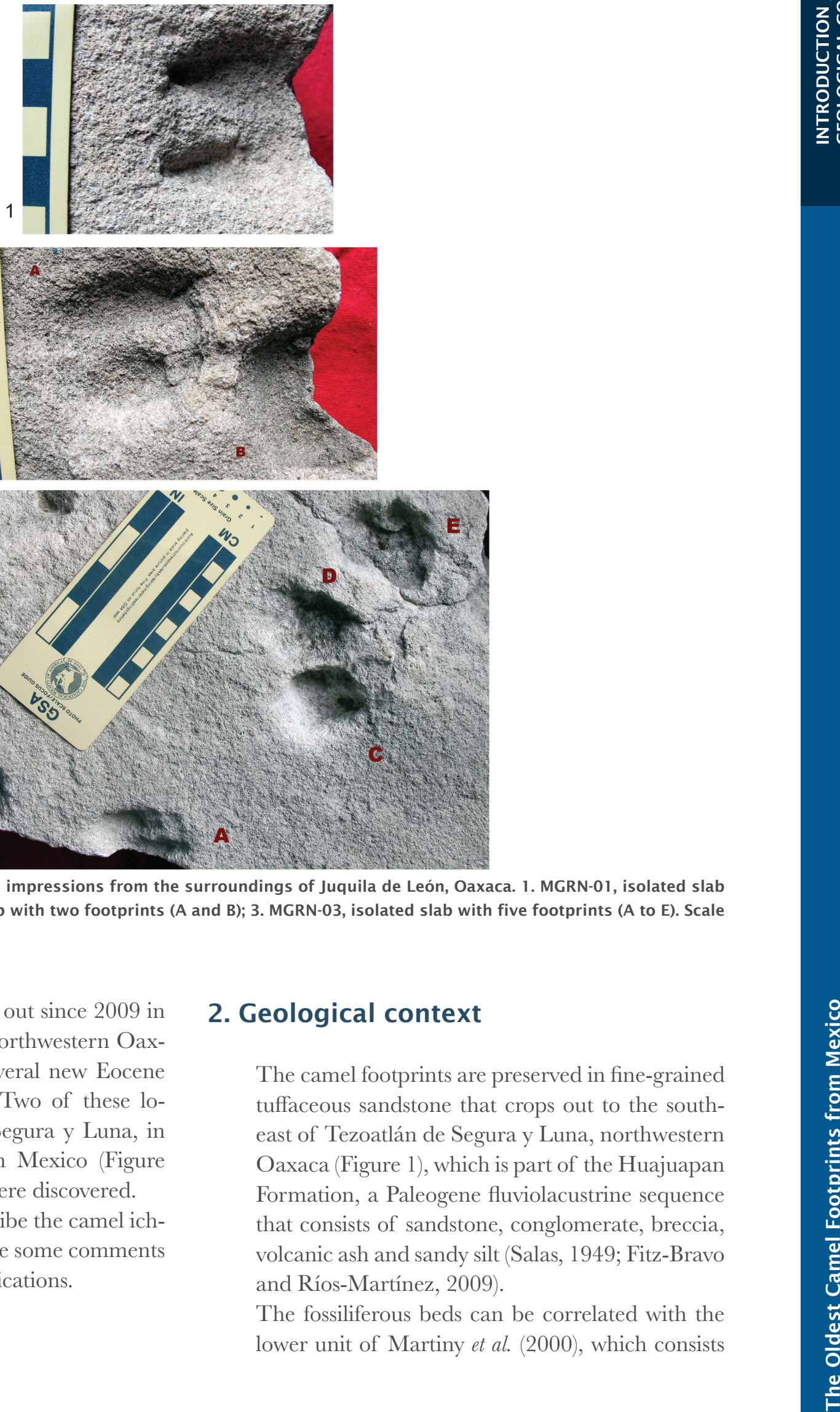

Figure 2 Late Eocene-early Oligocene camel impressions from the surroundings of Juquila de León, Oaxaca. 1. MGRN-01, isolated slab with one footprint; 2. MGRN-02, isolated slab with two footprints (A and B); 3. MGRN-03, isolated slab with five footprints (A to E). Scale is in $\mathrm{cm}$.

Paleontological research carried out since 2009 in the Paleogene sediments from northwestern Oaxaca, has allowed us to study several new Eocene and Oligocene fossil localities. Two of these localities are near Tezoatlán de Segura y Luna, in northwestern Oaxaca, southern Mexico (Figure 1), where some camel ichnites were discovered.

The aim of this paper is to describe the camel ichnites from Tezoatlán and to make some comments about their paleobiological implications.

\section{Geological context}

The camel footprints are preserved in fine-grained tuffaceous sandstone that crops out to the southeast of Tezoatlán de Segura y Luna, northwestern Oaxaca (Figure 1), which is part of the Huajuapan Formation, a Paleogene fluviolacustrine sequence that consists of sandstone, conglomerate, breccia, volcanic ash and sandy silt (Salas, 1949; Fitz-Bravo and Ríos-Martínez, 2009).

The fossiliferous beds can be correlated with the lower unit of Martiny et al. (2000), which consists 
of a sequence of pyroclastic and epiclastic strata deposited in a lacustrine-fluvial environment. Two K-Ar dates of 33.6 $\pm 1.4 \mathrm{Ma}$ and $34.2 \pm 1.4$ $\mathrm{Ma}$ are available for the lower unit (Martiny et al., 2000), which suggest a late Eocene-early Oligocene age for the ichfossiliferous beds.

\section{Materials and Methods}

The studied material consists of 11 footprints in concave epirelief (Figures 2 and 3). Eight footprints are preserved in three slabs collected from the surroundings of Juquila de León, which are now on exhibition at the Museo Geológico de Rosario Nuevo (MGRN), located in the town of Rosario Nuevo. Three additional ichnites were discovered in a sandstone bed near the road to El Naranjo.

Measurements were taken as maximum length and width and are expressed in $\mathrm{mm}$.

We followed the camel ichnotaxonomy of Lucas and Hunt (2007).

Potential producer's limb length was estimated based on measurements of Prothero (1996) and the body mass estimations of potential producers were derived from the data of Prothero (1996) and the predictive equations of Janis (1990).

\section{Systematic ichnology}

Class Mammalipedia Vialov, 1966

Order Artiodactipedida Vialov, 1966

Morphofamily Pecoripedidae Remeika et al., 1995 Ichnogenus Lamaichnum Aramayo and Bianco, 1987

Lamaichnum guanicoe Aramayo and Bianco, 1987

Referred material. MGRN-01, isolated slab with one footprint; MGRN-02, isolated slab with two footprints; MGRN-03, isolated slab with five well preserved footprints. Three footprints pre-
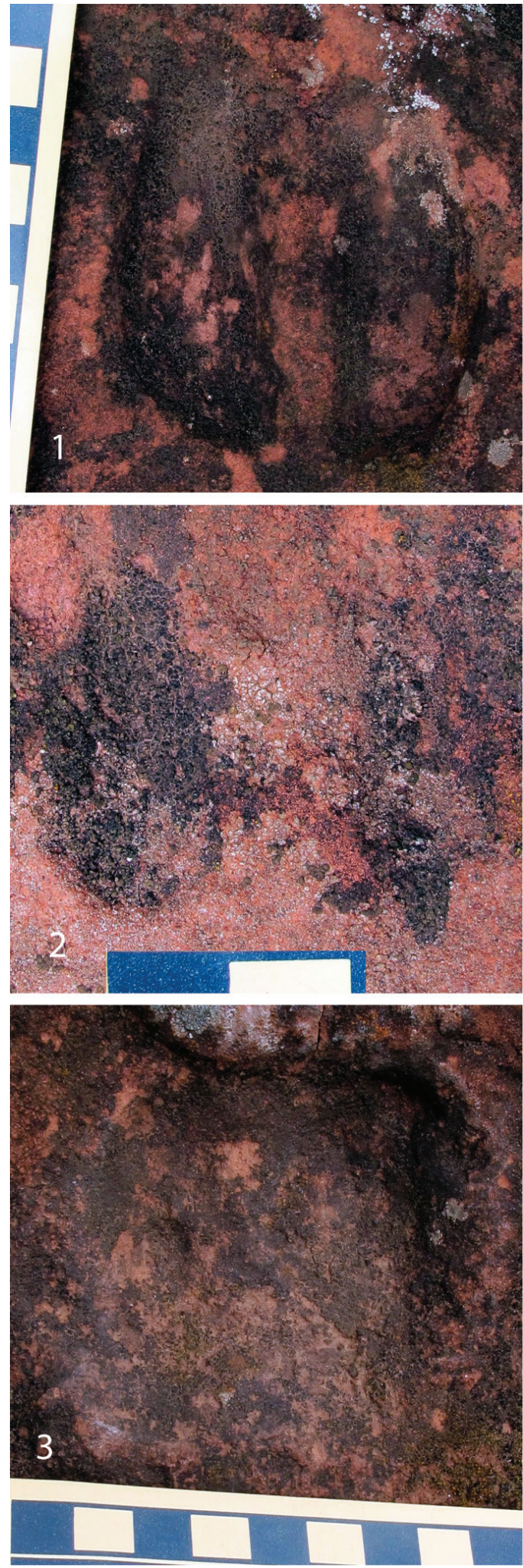

Figure 3 Late Eocene-early Oligocene camel impressions from the road to El Naranjo, Oaxaca. 1. Footprint H1; 2. Footprint H2, which appears to represent an underprint; 3. Footprint H3; note the push up of sediment in the rear of the print. Scale is in $\mathrm{cm}$. 
Table 1. Measurements of Lamaichnum guanicoe footprints from the late Eocene-early Oligocene of Tezoatlán, Oaxaca.

\begin{tabular}{|c|c|c|c|}
\hline Specimen & Length $(\mathbf{m m})$ & Width $(\mathbf{m m})$ & Depth $(\mathbf{m m})$ \\
\hline MGRN-01 & & 38 & 12 \\
\hline MGRN-02.A & 45 & 40 & 10 \\
\hline MGRN-02.B & & 40 & 16 \\
\hline MGRN-03.A & 65 & & 26 \\
\hline MGRN-03.B & 60 & & 24 \\
\hline MGRN-03.C & 45 & 39 & 21 \\
\hline MGRN-03.D & 50 & 42 & 13 \\
\hline MGRN-03.E & 55 & 42 & \\
\hline H1 & 65 & 61.3 & 12 \\
\hline H2 & 31 & 33 & 14 \\
\hline H3 & 64 & 59 & 16.4 \\
\hline Mean & 53.3 & 43.8 & 5.8 \\
\hline SD* & 11.6 & 9.6 & \\
\hline
\end{tabular}

* Standard deviation.

served in a sandstone bed located near the road to El Naranjo.

Description. Footprints are longer than wide (length/width ratio $=1.21)($ Table 1$)$, with an ovoid outline, with two digit impressions and rounded posterior ends. The digit impressions are parallel or slightly divergent and are separated by an anterior cleft/interclavular gap (Figures $2-4$ ). Two nail impressions are evident in most of the ichnites (Figure 4). The axial surface of all prints is antero-posteriorly convex, not flat. The footprints are 10 to $26 \mathrm{~mm}$ in depth (Table 1).

Some ichnites show extramorphological variation, such as a continuous interdigital sulcus (Figure 3.1) or an absent posterior cleft (Figure 3.1). One footprint is smaller and shallower than the others, so, it probably represents an underprint (Figure 3.2).

Discussion. The ichnites from Oaxaca show the diagnostic features of Lamaichnum, such as: bidigital tracks with pointed anterior ends and rounded posterior ends, with digit impressions that do not converge anteriorly and footprints that have digit imprints connected (Lucas and Hunt, 2007).

The studied footprints have a mean length of 53.3 $\mathrm{mm}$ (Table 1), which falls within the lower limit of the reported length range of Lamaichnum guanicoe (Lucas and Hunt, 2007). Thus, the Oaxacan prints can be confidently assigned to this ichnospecies.

The identification of the Tezoatlán footprints as Lamaichnum guanicoe does not imply that we assume that the potential track maker was Lama guanicoe, as Aramayo and Bianco (1987) suggested when the ichnospecies was erected. The oldest record of lamine camels is early Miocene in age (Honey et al., 1998), more than 14 million years younger than the estimated age of the ichnofossiliferous beds. Potential track makers should be members of the first camel radiation that occurred during the late Eocene-early Oligocene (Honey et al., 1998), as will be discussed below.

\section{Paleobiological implications of the Oaxacan footprints}

The published Mexican record of camel ichnites includes Miocene and Plio-Pleistocene localities in northwestern, western and central Mexico (Figure 1). The Lamaichnum guanicoe footprints from Tezoatlán, Oaxaca, represent the first published Paleogene record in the country and are amongst the oldest camel ichnites in North America (Chaffee, 1943; Bjork, 1976; Sarjeant and Langston, 1994). Characteristics of the camel footprints from Tezoatlán, Oaxaca do indicate some of the foot's producer anatomy. The concave axial surface of the imprints (instead of a flat surface) indicates the presence of fleshy digital cushions, similar to those of extant camels (Thomson et al., 2007). The nail imprints, clearly differentiated from the digit impressions (Figure 4), indicate the presence of anterior nails in the foot of the track makers, similar to those of extant camels, and not cloven hooves (see figure 1 of Lucas and Hunt, 2007). Therefore, the camelids that produced the imprints from the Eocene-Oligocene of Oaxaca, shared some anatomical pedal features with extant camels.

The oldest osteological record of camels from Mexico comes from the late Eocene localities of Yolomécatl, Oaxaca, where Poebrotherium was reported (Jiménez-Hidalgo et al., 2015b). Also, recently collected new postcranial specimens indicate the presence of another camelid taxon in Yolomécatl. These records are to the southeast of Tezoatlán de Segura y Luna. 

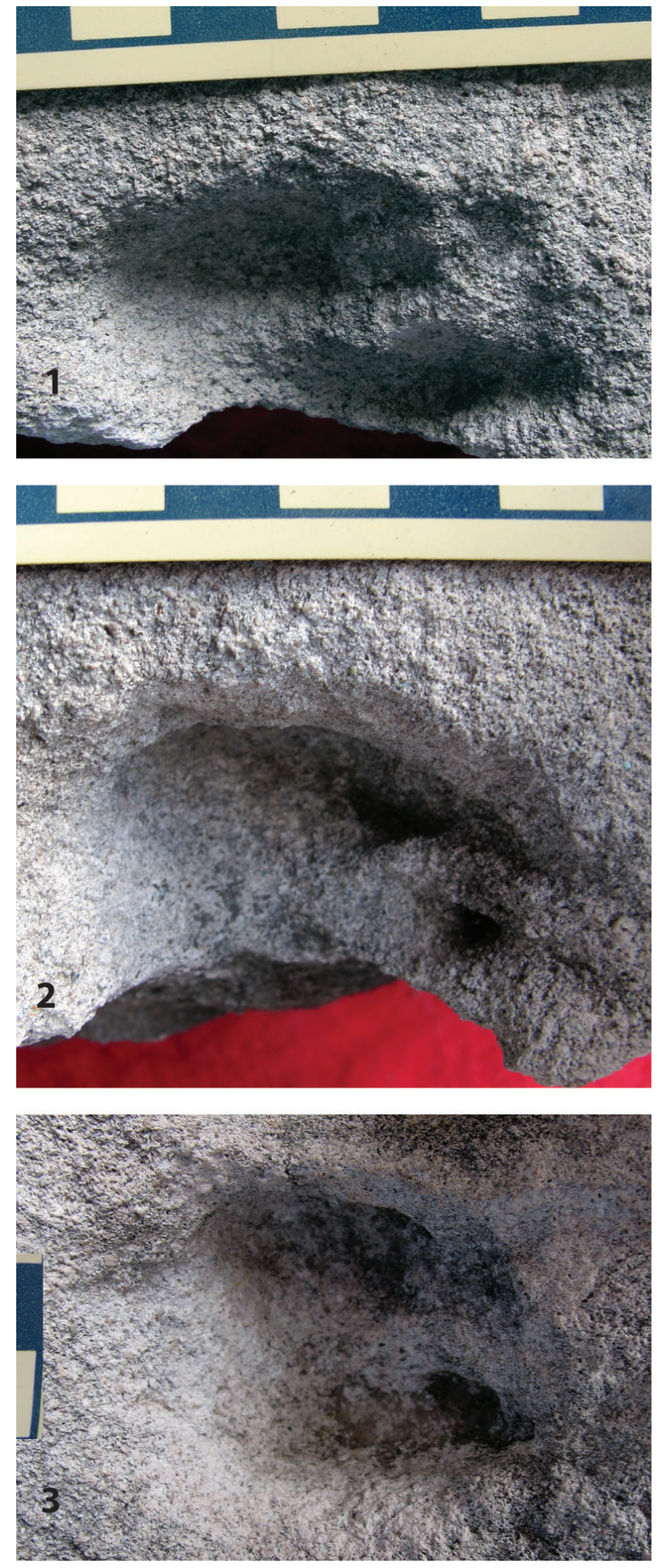

Figure 4 Close-up of some footprints of slab MGRN-03. 1. Ichnite MGRN-03.A; 2. MGRN-03.B; 3. MGRN-03.C. Note the nail imprints differentiated from the digit impressions, the concavity of footprints and the presence of an anterior cleft/interclavular gap. Scale is in $\mathrm{cm}$.
Given the late Eocene-late Oligocene geochronological record of Poebrotherium (Honey et al., 1998), it could be possible that some individuals of this taxon would be the potential track makers of the ichnites from Oaxaca. However, the pedal anatomy of Poebrotherium is similar to that of typical ruminants: the ungual phalanges are long, high and pointed, resembling those of pronghorn and deer, and its foot lacked the cushion that characterizes extant camel forms (Scott and Jepsen, 1940; Honey et al., 1998). Hence, giving the observed characters of the L. guanicoe imprints here studied, Poebrotherium can be excluded as a potential track maker.

The camel Paratylopus has a geochronological range from late Eocene to early Oligocene, Paralabis has been recorded from the early Oligocene, and Pseudolabis has a geochronological range from the early Oligocene to the early Miocene of North America (Honey et al., 1998). These genera are within the temporal range estimated for the ichnofossiliferous beds of Tezoatlán; therefore, it is possible that individuals of these taxa produced the Oaxacan footprints. These potential track makers were medium-sized camels, with an estimated body mass and limb length comparable to the smallest living camelid Vicugna vicugna (Table 2). In Paratylopus and Pseudolabis the metapodials are somewhat divergent at their distal end, in Pseudolabis the metapodials are partially fused and its foot morphology is intermediate between that of ruminants and lamine camelids (Janis et al., 2002). The postcranial skeleton of Paralabis is unknown (Prothero, 1996).

The estimated body mass and limb length of Paratylopus and the estimated body mass of Paralabis make them good candidates as potential producers of the Oaxacan ichnites. Foot structure of Pseudolabis and the observed wide range of body masses of Vicugna, suggest that Pseudolabis cannot be ruled out as potential track maker, at least for the largest imprints.

The concave axial surface and nail imprints of the studied camel footprints suggests that some soft anatomical features of the peculiar camel foot 
Table 2. Body mass estimation and estimated limb length of potential trackmakers of Lamaichnum guanicoe footprints from the late Eocene-early Oligocene of Tezoatlán, Oaxaca and the extant lamine camel Vicugna vicugna.

\begin{tabular}{|c|c|c|c|c|c|}
\hline & $\begin{array}{c}\text { Paratylopus } \\
\text { labiatus }\end{array}$ & $\begin{array}{l}\text { Paratylopus } \\
\text { primaevus }\end{array}$ & $\begin{array}{l}\text { Paralabis } \\
\text { cedrensis }\end{array}$ & $\begin{array}{c}\text { Pseudolabis } \\
\text { dakotensis }\end{array}$ & $\begin{array}{l}\text { Vicugna } \\
\text { vicugna }\end{array}$ \\
\hline \multirow{3}{*}{$\begin{array}{l}\text { Body mass } \\
\quad(\mathrm{kg})\end{array}$} & \multirow{3}{*}{25} & \multirow{3}{*}{26.7} & \multirow{3}{*}{32.6} & \multirow{3}{*}{45.57} & $22-54^{\mathrm{a}}$ \\
\hline & & & & & $35-65^{b}$ \\
\hline & & & & & $44.97^{\mathrm{c}}$ \\
\hline \multirow{3}{*}{$\begin{array}{l}\text { Limb length } \\
\quad(\mathrm{mm})\end{array}$} & \multirow{3}{*}{682} & \multirow{3}{*}{--} & \multirow{3}{*}{--} & \multirow{3}{*}{875} & $668.34^{\mathrm{b}}$ \\
\hline & & & & & $760-860$ \\
\hline & & & & & $\begin{array}{c}\text { (shoulder } \\
\text { height) }^{\mathrm{c}}\end{array}$ \\
\hline
\end{tabular}

Data from: a) Quispe et al. (2010); b) Christiansen (2002); c) Walker (1964).

had already evolved by the late Eocene-early Oligocene; this was also independently determined based on osteological evidence by Janis et al. (2002).

\section{Conclusions}

The late Eocene-early Oligocene Lamaichnum guanicoe footprints from Tezoatlán, Oaxaca, represent the oldest record of this ichnospecies in Mexico and one of the oldest records of camel imprints in North America.

Given their geochronological range, it is probable that some individuals of Paralabis, Pseudolabis and/ or Paratylopus produced the camel impressions from Oaxaca. The genus Poebrotherium can be excluded as track maker given its foot morphology.

The footprint morphology of the studied impressions reflect the presence of some anatomical foot features of extant camels in the trackmakers, which indicates that by the late Eocene-early Oligocene some camel taxa had some anatomical features of the distinctive camel foot.

\section{Acknowledgements}

We kindly acknowledge Sara Quiroz Barroso for invited us to participate in this special number. The comments of Spencer G. Lucas and Victor Manuel Bravo Guevas helped to improve this paper. We are grateful to Jorge Jiménez Rentería for his kind attentions during our visits to Tezoatlán de Segura y Luna and to Rosario Nuevo. Mr. Xenon Daniel León Hernández discovered the first ichnite. We appreciate the suggestions of Torrey G. Nyborg for improving the English. This study was partially funded by CONACYT Ciencia Básica 2015 project No 255883 "Asociaciones faunísticas y ambientes de depósito de las localidades fosilíferas continentales del Eoceno tardío de la Mixteca Alta Oaxaqueña”.

\section{References}

Aramayo, S.A., Bianco, T.M., 1987, Hallazgo de una icnofauna continental (Pleistoceno Tardío) en la localidad de Pehuenco (Partido de Coronel Rosales), Provincia de Buenos Aires, Argentina. Parte II. Carnivora, Artiodactyla y Aves (resumen), in SuárezRiglos, M., Suárez-Soruco, R., IV Congreso Latinoamericano de Paleontologia: Santa Cruz de la Sierra, Bolivia, Asociación Boliviana de Paleontología, 532-547.

Bjork, P.R., 1976, Mammalian tracks from the Brule Formation of South Dakota: Proceedings of the South Dakota Academy of Sciences, 55, 154-158.

Cabral-Perdomo, M.A., 2013, Icnofósiles de vertebrados terrestres del Cenozoico Tardío en el área de "Pie de Vaca", Tepexi de Rodríguex, Estado de Puebla: Paleontología Mexicana, 3(1), 51-58. 
Chaffee, R.G., 1943, Mammal footprints from the White River Oligocene: Notulae Naturae of the Academy of Natural Sciences of Philadelphia, 116, 1-13.

Christiansen, P., 2002, Locomotion in terrestrial mammals: the influence of body mass, limb length and bone proportions on speed: Zoological Journal of the Linnean Society, 136, 685-714.

Dávalos-Álvarez, O.G., Nieto-Samaniego, A.F., Alaniz-Álvarez, S.A., Martínez-Hernández, E., Ramírez-Arriaga, E., 2007, Estratigrafía cenozoica de la región de Tehuacán y su relación con el sector norte de la falla de Oaxaca: Revista Mexicana de Ciencias Geológicas, 24, 197-215.

Fitz-Bravo, C., Ríos-Martínez, D., 2009, Carta geológico-minera Tezoatlán de Segura y Luna E14-D24, 1:50000: Pachuca, Hidalgo, México, Servicio Geológico Mexicano, 1 mapa.

Honey, J.G., Harrison, J.A., Prothero, D.R., Stevens, M.S., 1998, Camelidae, in Janis, C.M., Scott, K.M., Jacobs, L.L. (eds.), Evolution of Tertiary Mammals of North America, Volume 1: Terrestrial Carnivores, Ungulates and Ungulatelike Mammals: New York, U.S.A., Cambridge University Press, 439-462.

Janis, C.M., 1990, Correlation of cranial and dental variables with body size in ungulates and macropodoids, in Damith, J., MacFadden, B.J. (eds.), Body size in mammalian Paleobiology: estimation and biological implications: New York, U.S.A., Cambridge University Press, 255-299.

Janis, G.M., Theodor, J.M., Boisvert, B., 2002, Locomotor evolution in camels revisited: a quantitative analysis of pedal anatomy and the acquisition of the pacing gait: Journal of Vertebrate Paleontology, 22, 110-121.

Jiménez-Hidalgo, E., Carbot-Chanona, G., Castañeda-Posadas, C., 2015a, El registro de mamíferos fósiles de Puebla, in CastañedaPosadas, C. (coord.), El registro paleobiológico del estado de Puebla: Puebla de Zaragoza, México, Escuela de Biología, Benemérita Universidad Autónoma de Puebla, 171-184. Jiménez-Hidalgo, E., Smith, K.T., GuerreroArenas, R., Alvarado-Ortega, J., 2015b, The First Late Eocene Continental Faunal Assemblage from Tropical North America: Journal of South American Earth Sciences, 57, 39-48.

Lockley, M.G., Bishop, W., 2014, New footprint evidence of avian and mammal activity from a Miocene site near Durango, Mexico, in Lockley, M.G., Lucas, S.G. (eds.), Fossil Footprints of Western North America: New Mexico Museum of Natural History \& Science Bulletin, 62, 501-507.

Lockley, M.G., Delgado, C.R., 2007, Tracking an ancient turkey: a preliminary report on a new Miocene ichnofauna from near Durango, Mexico, in Lucas, S.G., Spielmann, J.A., Lockley, M.G. (eds.), Cenozoic vertebrate tracks and traces: New Mexico Museum of Natural History \& Science Bulletin, 42, $67-72$.

Lucas, S.G., Hunt, A.P., 2007, Ichnotaxonomy of camel footprints, in Lucas, S.G., Spielmann, J.A., Lockley, M.G. (eds.), Cenozoic vertebrate tracks and traces: New Mexico Museum of Natural History \& Science Bulletin, 42, 155-168.

Martiny, B., Martínez-Serrano, R.G., MoránZenteno, D.J., Macías-Romo, C., Ayuso, R.A., 2000, Stratigraphy, geochemistry and tectonic significance of the Oligocene magmatic rocks of western Oaxaca, southern Mexico: Tectonophysics, 318, 71-98.

Prothero, D.R., 1996, Camelidae, in Prothero, D.R., Emry, R. (eds.), The terrestrial EoceneOligocene transition in North America: New York, U.S.A., Cambridge University Press, 609-651.

Quispe, E.C., Ramos, H., Mayhua, P., Alfonso, L., 2010, Fibre characteristics of vicuña (Vicugna vicugna mensalis): Small Ruminant Research, 93, 64-66. 
Remeika, P., Jefferson, G.T., Murray, L.K., 1995, Fossil vertebrate faunal list for the VallecitoFish Creek and Borrego-San Felipe Basins, Anza-Borrego Desert State Park and vicinity, California, in Remeika, P., Sturz, A. (eds.), Paleontology and Geology of the Western Salton Trough Detachment, Anza-Borrego Desert State Park, California: San Diego, U.S.A., San Diego Association of Geologists, Field Trip Guidebook, I, 82-93.

Rodríguez-de la Rosa, R.A., Guzmán-Gutiérrez, J.R., 2012, Huellas de aves y mamíferos del Neógeno de Jalisco, México: Paleontología Mexicana, 62, 147-158.

Salas, G.P., 1949, Bosquejo geológico de la Cuenca sedimentaria de Oaxaca: Boletín de la Asociación Mexicana de Geólogos Petroleros, 1, 79-156.

Sarjeant, W.A.S., Langston, W.jr., 1994, Vertebrate footprints and invertebrate traces from the Chadronian (Late Eocene) of Trans-Pecos Texas: Texas Memorial Museum Bulletin, $36,1-86$.
Scott, W.B., Jepsen, G.L., 1940, The mammalian fauna of the White River Oligocene: Part IV. Artiodactyla: Transactions of the American Philosophical Society, 28, 363-746.

Thomson, M.E., White, R.S.jr., Morgan, G.S., 2007, Pace versus trot: can medium speed gait be determined from fossil trackways?, in Lucas, S.G., Spielmann, J.A., Lockley, M.G. (eds.), Cenozoic vertebrate tracks and traces: New Mexico Museum of Natural History \& Science Bulletin, 42, 309-314.

Vialov, O.S., 1966, Sledy zhiznedeyatelnosti organizmov i ikh paleontologicheskoe znacheniye: Kiev, Ukraine, Akademiya Nauk Ukrainskoy SSR Institut Geologii I Geokhimii Goryuchikh Inskopayemykh, Naukova Dumka, 219 p.

Walker, E.P., 1964, Mammals of the world, volume II: Baltimore, U.S.A., Johns Hopkins Press, 854 p. 